\title{
THE EFFECT OF ECONOMIC FACTORS ON PERFORMANCE OF THE STOCK MARKET IN THE CZECH REPUBLIC
}

\author{
Tomáš Pražák ${ }^{1}$ \\ 'Department of Finance and Accounting, School of Business Administration, Silesian University, Univerzitní nám. \\ 1934/3, 73340 Karviná, Czech Republic
}

To cite this article: PRAŽÁK TOMÁŠ. 2018. The Effect of Economic Factors on Performance of the Stock Market in the Czech Republic. Acta Universitatis Agriculturae et Silviculturae Mendelianae Brunensis, 66(6): 1613-1626.

To link to this article: https://doi.org/10.11118/actaun201866061613

\begin{abstract}
History has shown that the stock prices and other financial assets are important aspects of the dynamics of economic activity. Stock prices can be an indicator of social mood and are used as a leading factor in the economic activity and financial stability. This paper investigates the relationship between selected macroeconomic and microeconomic factors and stock prices of companies listed on the Prague Stock Exchange. The portfolio theory and Capital Asset Pricing Model for specification of stock market are used. Johansen and Juselius (1990) and Hansen (1982) approaches are applied to test for causal relationship. In addition, the Vector error correction model for equilibration of a potential long-run relationship between variables is used. Selected macroeconomic and microeconomic factors provide a statistically significant relationship on stock prices during the observed period from 2006 to 2016. However, the results differ substantially among the sectors of economic activity, the industrial production, the gros domestic product and profitability ratios in particular, can explain a long-run behavior of stock prices.
\end{abstract}

Keywords: stock prices, macroeconomic factors, microeconomic factors, cointegration, CAPM

\section{INTRODUCTION}

The basic notion of the stock market is the market value of the stocks. We can find market value simply from online ticketing lists or dedicated websites that provide market rates for stock in real-time. Fundamental analysis is based on the fact that this market value oscillates around the internal value. The market value of publicly traded shares is determined by demand and supply on the stock exchange. Shares represent a very risky investment because its market price is subject to fluctuations due to investors' expectations regarding the development of corporate underlying factors (liquidity, company debt, profitability, etc.), macroeconomic and political environment, and the psychological mood of the market.
The fundamental analysis identifies and evaluates the relationship between stock price development and economic factors. From the perspective of firms, macroeconomic and microeconomic conditions are the main influencing factors. The fundamental analysis should reflect all the major corporate characteristics. The implied assumption of the fundamental analysis is that at any time, an individual security has an equilibrium price. Equilibrium price depends on the earning prospect of the security. The earning prospect of the security depends in turn on fundamental factors such as the structure of the company, quality of management, outlook for the industry and the economic environment. 
The global fundamental analysis focuses on the impact of the entire economy on the stock prices. At the global level, the basic analysis focuses on the impacts of macroeconomic data such as gross domestic product, inflation, unemployment, interest rate or consumer demand.

The aim of this paper is to characterize the stock market in the Czech Republic with focus on examining of the character of the relationship between stock price development and economic factors in the Czech Republic. In the first part of this paper, it will be necessary to characterize the Prague stock exchange through a special case of the Markowitz portfolio model using the Capital asset pricing model (CAPM). The development of the stock market and the stock price is affected by the economic environment. In this paper, economic factors are represented by selected macroeconomic fundamentals and financial ratios of companies on the Prague Stock Exchange (PX). The relationship between stock prices and economic factors is investigated through the econometric analyses in modern econometric software Eviews. The observed period of variables under investigation is from the first quarter of 2006 to the fourth quarter of 2016.

Although the mutual influence of stock prices and economic factors is a frequent topic of studies, the long-term causal relationship between economic indicators and stock prices, was overlooked in the case of the Czech Republic. The stock market and the economic situation in the Czech Republic have been characterized as highly volatile with a low number of stock titles. In recent years, thanks to the stable economic situation, with regular GDP growth, low unemployment and a healthy banking sector, the Czech Republic has become an attractive economy for investors. The Czech Republic is a small open economy with a fast-growing financial market. The Prague Stock Exchange, a.s. is the largest and oldest securities market organization in the Czech Republic. Trading on the PX takes place through licensed securities dealers who are also members of the exchange. These are mainly major banks and brokerage firms. The domestic market capitalization of PX is actual 23,4 bn. EUR and the PX is composed of 25 listed companies. Last years were significant mainly by the Moneta Money's IPO. This issue has become, in many parameters, the most significant European emissions in recent years. It was the largest emissions in European regulated markets in the first half of 2016 and was also the fastest $100 \%$ exit over the capital market for the past 10 years in EMEA (Europe, Middle East and Africa) stock markets.

Investor demand analyzes portfolio theory on assets assuming knowledge of the yield of the assets in question. It deals with the relationship between risk and return and how they affect demand and supply. Portfolio theory seeks to explain how the investor can maximize yield and minimize the associated risk. Modern portfolio theory presents the concept of risk diversification. The aim is to create a portfolio whose overall risk is less than the risk of individual assets in the portfolio. As a result of the CAPM share valuation, the expected yield of the individual shares is depicted using the Security market line (SML), which can be used as the basis for the investor's decision on the stock's worth.

In particular, this paper also tests for long-term equilibrium relationships and also analyzes short-term dynamics and transmission of shocks from the macroeconomic environment to the stock market. Information on the impact of economic factors on stock prices is an important finding for investors and company management. On contrary, the linear regression model for the relationship between microeconomic fundamentals and stock prices is also used. The dataset consists of the stock prices of the following corporations listed on the PX: ČEZ AG (ČEZ), Energoaqua AG (ENER), Erste Group Bank AG (ERST), Komerční Banka AG (KOME), O2 Czech Republic AG (O2), Pegas Nonwovens AG (PEG), Phillip Morris ČR (PHIL), TOMA AG (TOMA), and Unipetrol (UNIP). These companies has the longest history on market and they are suitable for analyzes. The macroeconomic variables used in the estimation are index of gross added value (GAV; y-o-y indices), harmonized index of product prices (HIPP), index of industrial production (INDP; $\mathrm{y}-\mathrm{O}-\mathrm{y}$ indices), index of real gross domestic product (GDP; y-o-y indices), unemployment rate (UNE) and consumer price index (CPI). The financial ratios under investigations are return on assets (ROA), return on equity (ROE), liquidity ratios Ll (cash position ratio) and L2 (current ratio), financial leverage (LEV) and debt-equity ratio (DE).

The rest of the paper is organized as follows. The relevant literature on the examined topic is reviewed in Section 2. The data and methodology used in the paper are introduced in Section 3. The results of empirical estimation are reported in Section 4 and discussion is reported in Section 5. The paper concludes with Section 5 in which the summary of the main findings is provided.

\section{Review of Literature}

The basis of portfolio theory is the model used to determine the theoretically appropriate rate of return of an asset, to make decisions about adding assets to a well-diversified portfolio. The Capital Asset Pricing Model (CAPM) is a special case of Markowitz's portfolio model, in which just one asset in the portfolio has both a free risk and a positive return. The model takes into account the asset's sensitivity to non-diversifiable risk (also known as systematic risk or market risk), often represented by the quantity beta ( $\beta$ ) in the financial industry, as well as the expected return of the market and the expected return of a theoretical risk-free asset. Modern portfolio theory presents the concept of risk diversification. The aim is to create a portfolio whose overall risk is less than the risk of individual assets in 
the portfolio. This is possible due to the fact that there is a prerequisite for a normal risk distribution of individual assets and therefore the risks of individual assets are interrupted. The CAPM takes into account the asset's sensitivity to non-diversifiable risk, often represented by the beta in the financial industry, as well as the expected return of the market and the expected return of a theoretical risk-free asset.

Markowitz (1952) divides the investment process into two parts. First, the investor creates an idea of the expected performance of assets based on experience and market observation. The second phase is based on the expected asset parameters to choose their composition. When compiling the portfolio, the investor has two opposing goals. On one side is his to maximize the expected return on the portfolio. If the investor only had this objective, then he would choose the asset with the highest yield. Because future asset yields include an element of uncertainty, however, it is always the largest expected return on the portfolio. Expected returns, but they certainly do not guarantee real future earnings. Portfolio selection based on maximization expected profit would lead to the selection of only one asset with the highest yield. For more assets with the same return, any combination of these two assets will be as valuable to the investor. For this reason, the investor should be interested in the element of uncertainty, for example, in the form of an economic situation, in addition to the yield that is desirable.

Lund and Engsted (1996) analyzed the consumption oriented CAPM with constant relative risk aversion using time series data from the Danish, German, Swedish and UK stock markets. According to their results, the dividend-price ratio generally predicts future dividend growth in the direction implied by the model. Similarly, the behavior of UK stock prices and returns explaining by the CAPM was described also by Cuthbertson et al. (2012). Their results confirmed the evidence of short-termism of the market efficiency. One of the main objectives of CAPM is to calculate the systematic risk (beta) factor. Sahadev et al. (2018) focused on the ability to accurately estimate systematic risk when reference day risk is considered. Furthermore, this paper also applied a graphical time series approach to testing the underlying risk-reward tenet postulated by CAPM. The appropriateness of using CAPM on aggregate stock market price confirmed Curran and Velic (2018). Their results showed that the positive risk-reward relation can collapse during times of high volatility. Their results also confirmed that countries with higher levels of financial and trade openness and larger economic size are exposed to higher systematic covariances with the volatility of the world stock market.

There are two different approaches to the valuation of stocks and economic factors; technical analysis and fundamental analysis. Trading strategy for the semi-strong test is the fundamental analysis that is based on the idea that the new information is not reflected in market prices.
Global fundamental analysis was an important and debatable issue of several researchers. Chen et al. (1986) investigated whether a development of macroeconomic variables are risks that are rewarded in the stock market. The paper confirmed that interest rates, inflation or industrial production systematically affect stock market. Gjerde and Saettem (1999) examine the causal relation between stock developments and the macroeconomic variables. The results show a positive relationship for oil price index and real economic activity. Similarly, the study by Flannery and Protopapadakis (2002) revaluates the effect of some macro announcement series on US stock returns. Among these series, six macro variables, namely, balance of trade, housing starts, employment, consumer price index, Ml and producer price index seem to affect stock returns. On the other hand, two popular measures of aggregate economic activity (real GNP and industrial production) do not appear to be related with stock market development.

According to the research area of this study, the following studies under investigation will be focused on the Central and Eastern European countries. Angelache et al. (2014) examine the long-term dynamic linkages between a set of macro financial variables and stock market indices of the Czech Republic, Hungary, Poland and Romania using a Vector Autoregressive model. The VAR model showed that there was a significant impact between observed variables mainly during the global financial crises. Similarly et al. (2015) discussed the same relationship. The indicators which significantly affected stock market development were gross domestic product, inflation, interest rate or unemployment rate. Barbič and Čondič (2011) analyzed the relationship between stock market indices and macroeconomic variables in the Czech Republic, Croatia, Hungary, Poland and Slovenia. In order to test for bilateral long run equilibrium relationships, the Johansen cointegration method was used. The study identified a long run relationship between observed variables especially in case of the Czech Republic and Poland. The causal linkage between stock prices, economic output, and money supply development in Central and Eastern European countries was investigated also by Kulhánek (2012). He reviewed quarterly data from 1995 to 2012 in his analysis. Based on the cointegration tests, and the vector autoregressive and vector error correction models, it was discovered that, there is a long-term cointegration relationship among the variables investigated.

According to Ali (2011) or Chen et al. (1986), the fundamental analysis also goes into the depth of a particular company. It seeks to find the right internal price of the stock by exploring information that is accessible to the public. These are economic, accounting, statistical data, as well as political, historical and demographic factors. The investor compares the derived price to the current financial market valuation. 
The importance of the relationship between stock price development and financial ratios in the Central and Eastern European countries is analyzed in the following studies. Bistrova, Lace and Titko (2013) analyzed the relationship between the market and economic performance of the Central and Eastern European companies'. Research including the Czech Republic, Poland, Slovakia and Slovenia were processed by correlation. The study confirmed that Pearson correlation analyses was insignificant or even negative in the majority of cases. The capital structure of listed firms in Visegrad countries was investigated by Bauer (2004). Furthermore, the differences in capital structure and potential determinants of financial leverage were provided. According to the results, the financial leverage is negatively correlated with profitability and tangibility, but positively correlated with stock price development. Several of these important variables include: earnings, dividends, cash flow projections, net assets, returns on capital employed, return on assets, liquidity ratio or debt to equity ratio.

\section{MATERIALS AND METHODS}

\section{Data characteristics}

Based on the literature review, appropriate indicators were selected to characterize macroeconomic and microeconomic factors that have an impact on stock price developments. All variables are further described in this section with the expected relationships between the selected variables. The analysis of the relationship between macroeconomic factors and stock prices is based on the quarterly observed period of data taken from the Investing database, Amadeus database and the national database of the Czech National Bank ARAD. By contrast, the relationship between microeconomic data (financial ratios) and stock prices is based on average annual values due to drawing data from annual statements of selected companies. The development of stock prices of the main PX index is described in Fig. 1.

The development of the PX index confirms the claim about stock price volatility in the Czech market. The biggest slump occurred during the global financial crisis in the second half of 2008 and at the time of the European debt crisis in 2011. The following period since 2014 is already characterized by stable developments. For analyzes of the influence of selected factors, only companies operating on the market for the entire observed period will be used. Based on the selected period 2006-2016, exactly nine stock companies were selected. Tab. I shows the basic descriptive characteristics of selected companies, where Max and Min capture the maximum value and the minimum value of stock prices. The Std. shows a standard deviation of the value from their arithmetic mean. Jarque Bera test (J-B test) and probability (Prob.) characterize the likelihood of normal division of the time series of the dependent variable. The last factor is the market capitalization of individual companies, which determines its percentage share in the PX market.

According to the market capitalization values, it is obvious that the largest share of the PX market has services. ERST, KOME and O2 together account for more than $50 \%$ of total market capitalization. The largest share from the industrial companies approximately 20, 9\% has ČEZ. The global economic crisis, which affected world economy in the second half of 2008 and the beginning of 2009, influenced the high range of minimum and maximum values and the standard deviation. This economic structural change was followed by the debt crisis in 2011, which had a negative impact on the economy and share development.

PX development

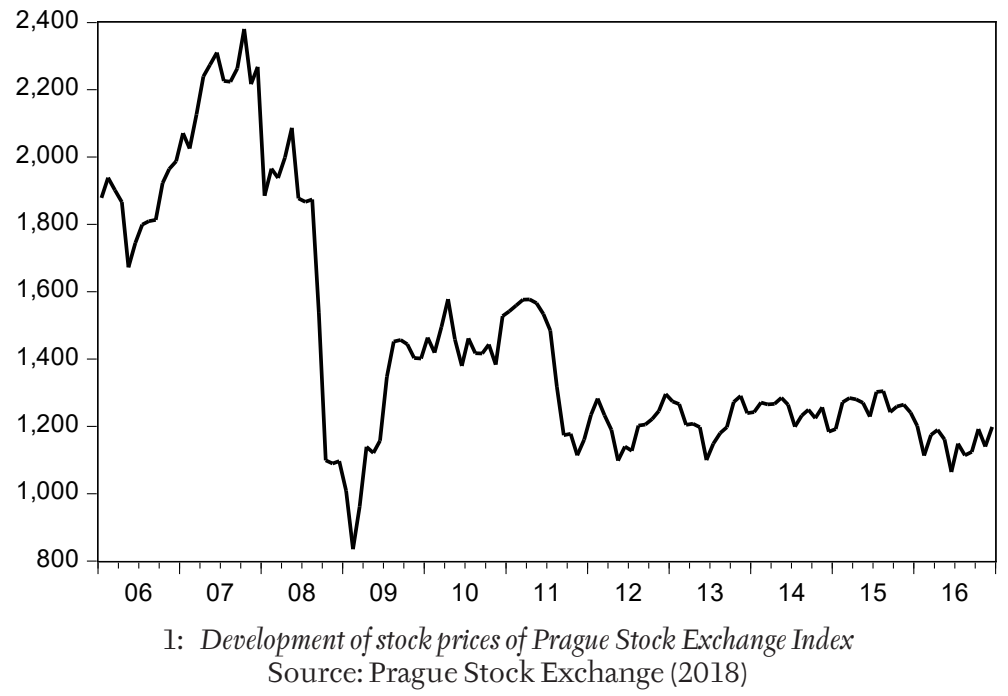


Important for the following econometric analysis is to recognize the normal distribution of the time series of the dependent variable. The zero hypothesis (HO) of the Jarque Berra test is that the time series reaches a normal distribution; on the other hand, the alternative $\mathrm{Hl}$ hypothesis is that the data does not have a normal distribution. Based on the Jarque Berra test's probability results, it can be concluded that HO cannot be rejected and thus the data has normal distribution. Time series with a normal distribution are suitable for statistical data processing by scale analysis. After determining the kind of dependent variable, this paper will be focused on the basic characteristics of the independent variables. Fig. 2 illustrates the development of major macroeconomic variables used in causal analyzes and Tab. II is described the descriptive statistics of macroeconomic variables.

The Czech economy is characterized by high share of the manufacturing industry in the structure of the economy (27\% of gross added value), by the long-term real convergence to developed countries (GDP per capita reached $87 \%$ of the EU), with a low inflation, where the price fluctuations are caused by the impact of administrative measures, or with the lowest unemployment rate in the EU. The growth of the Czech economy culminated in the second quarter of 2006 at a rate of $7.3 \%$. In 2009 , as a result of the global crisis, the domestic economy decreased into a deep recession, with GDP falling by $4.9 \%$. The signs of recovery have emerged already in 2010, mainly due to the positive trend in external demand, but in 2011 growth has slowed again. Renewed growth to $2.7 \%$ in 2014 and strong acceleration to $4.5 \%$ in 2015 was supported by one-off factors (fiscal stimulus, low oil price). In 2016, economic growth slowed down to $2.4 \%$, mainly as a result of the waning of EU funds.

In 2009, industrial output decreased by $13.6 \%$ year on year, followed by a two-year growth. Industry growth was renewed in 2014 (5.0\%) and continued

I: Descriptive statistics of stock prices

\begin{tabular}{lccccccccc}
\hline & ČEZ & ENER & ERST & KOME & O2 & PEG & PHIL & TOMA & UNIP \\
\hline Mean & 179.23 & 1791.3 & 804.51 & 800.87 & 115.11 & 576.27 & 10233 & 640.87 & 184.51 \\
Max. & 423.0 & 2722 & 1536 & 1060 & 239.1 & 776.2 & 12994 & 834.3 & 280.3 \\
Min. & 83.56 & 1370 & 444.4 & 584.3 & 66.94 & 366.2 & 5974 & 393.3 & 125.7 \\
Std. & 117.8 & 513.0 & 345.2 & 132.9 & 46.95 & 163.1 & 2120 & 147.2 & 44.75 \\
J-B test & 4.305 & 1.716 & 3.192 & 0.400 & 8.508 & 1.305 & 1.105 & 0.555 & 1.075 \\
Prob. & 0.116 & 0.423 & 0.202 & 0.818 & 0.142 & 0.520 & 0.575 & 0.757 & 0.584 \\
Cap.* & $20,9 \%$ & $0,14 \%$ & $32,9 \%$ & $13,8 \%$ & $6,5 \%$ & $0,6 \%$ & $2,5 \%$ & $0,14 \%$ & $5,3 \%$ \\
\hline
\end{tabular}

Note: *Share of total market capitalization

Source: Investing, 2018 (author's calculations)

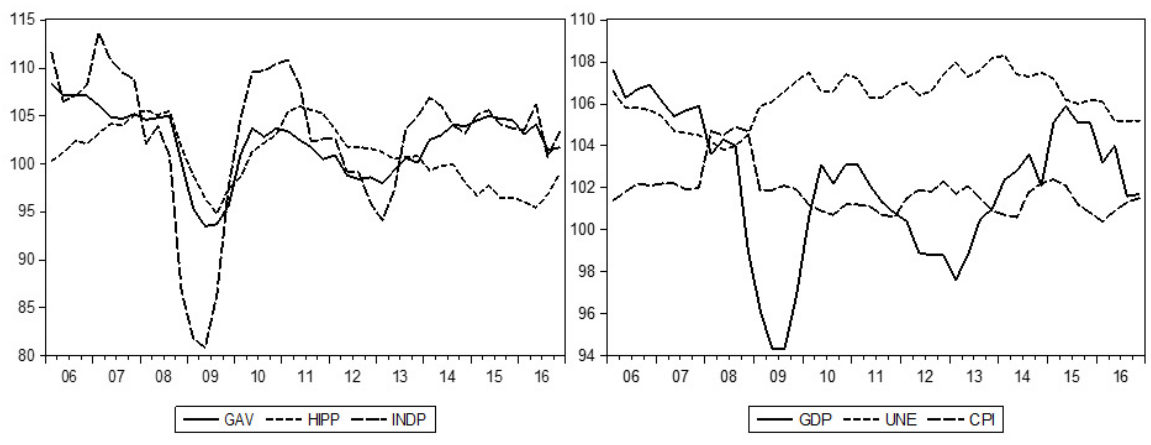

2: Development of selected macroeconomic variables (indexes) Source: ARAD, 2018 (author's calculations)

II: Descriptive statistics of macroeconomic variables

\begin{tabular}{lcccccc}
\hline & GAV & HIPP & INDP & GDP & UNE & CPI \\
\hline Mean & 102.27 & 100.87 & 102.81 & 102.20 & 106.27 & 101.80 \\
Max. & 108.40 & 106.00 & 113.70 & 107.60 & 108.30 & 104.90 \\
Min. & 93.50 & 94.80 & 80.80 & 94.30 & 103.80 & 100.40 \\
Std. & 3.52 & 3.22 & 7.44 & 3.32 & 1.16 & 1.07 \\
\hline
\end{tabular}

Source: ARAD, 2018 (author's calculations) 
in 2015 (4.6\%). In 2016, the growth rate slowed down to $2.9 \%$ due to the high benchmark base. In 2016, the leading share (expressed in volume of sales) in total industrial production was $22 \%$ in the automotive industry. Its growth has a positive impact on other supply and sub-contractors and industries. In 2016, total orders increased by $4.5 \%$, of which foreign (by 6.4\%) and domestic $(0.9 \%)$. The future development of the industry will depend largely on the demand for cars, but also on the development of other industries in partner countries (especially in Germany and in the European Union).

Tab. III and Tab. IV show the descriptive statistics and the mean values of the selected microeconomic indicators. The first group of selected microeconomic variables are indicators of indebtedness. The debt to equity ratio (DE) is a financial ratio that compares a company's total debt to total equity. The debt to equity ratio shows the percentage of company financing that comes from creditors and investors. A higher ratio indicates that more creditor financing (bank loans) is used than investor financing (shareholders). The debt to equity ratio is calculated by dividing total liabilities by total equity and all of the elements are reported on the balance sheet. According to descriptive statistic, it is possible to view that the DE has the highest ratio of standard deviation. The highest coefficients of DE have a banking companies ERST and KOME. Similarly, financial leverage, is an economic concept for the effect that an investor trades on the financial market not only with his own capital but also with the use of additional foreign capital. This will multiply the investment and result in a multiplier of profit or loss. The basic leverage effect is the use of additional foreign capital and financial derivatives are often used for leveraged trading. With smaller equity, investors can control more valuable assets.
The second group of variables are liquidity ratios L1 and L2. Liquidity can be defined simply as the ability of an economic entity to meet its obligations through its payment in cash. The Cash Position Ratio (also the liquidity of the first degree, L1) is an indicator that expresses the company's immediate ability to pay its short-term liabilities. Financial assets as cash, current accounts of the company and cash deposited in short-term marketable securities may be used to cover liabilities. The recommended value of ratio is between 0.2 and 0.5. The Quick Asset Ratio (also the liquidity of the second degree, L2) is the ratio measuring the difference between the current assets and short-term liabilities. The recommended liquidity value is between 1 and 1.5. This threshold is met by most companies, or they have come closer to this limit in the period under review. Only TOMA had values above the recommended limits.

The last indicators under investigation are ratios of profitability; the return on as-sets (ROA) and return on equity (ROE) ratios. The ROA ratio measures profit with the total assets invested in the business regardless of the way of financing. The important thing is whether an enterprise can effectively use its assets. The higher the value of the ROA is, the better, for the company's profitability. The return on assets ratio also reflects the coverage rate of the company's risky assets. On the contrary, The ROE indicator is a key ratio for shareholders and other investors. It represents the efficiency of the reproduction of the capital and it indicates how much net profit is per one crown of invested capital. Both of ratios of profitability reached the lowest value of standard deviation. The highest values of mean in the period under review were reached by $\mathrm{O} 2$ and PHIL, while the lowest had ERST and KOME.

On the basis of review of literature and economic theory, the expected effects of economic factors

III: Descriptive statistics of microeconomic variables

\begin{tabular}{lcccccc}
\hline & DE & LEV & L1 & L2 & ROA & ROE \\
\hline Mean & 2.89 & 3.35 & 0.39 & 1.22 & 0.08 & 0.14 \\
Max. & 14.61 & 13.61 & 1.65 & 3.52 & 0.36 & 0.44 \\
Min. & 0.09 & 0.64 & 0.01 & 0.41 & -0.09 & -0.18 \\
Std. & 4.23 & 3.47 & 0.41 & 0.50 & 0.09 & 0.11 \\
\hline
\end{tabular}

Source: Amadeus, 2018 (author's calculations)

IV: Mean values of selected microeconomic variables

\begin{tabular}{lccccccccc}
\hline & ČEZ & ENER & ERST & KOME & O2 & PEG & PHIL & TOMA & UNIP \\
\hline DE & 1.263 & 0.171 & 11.14 & 9.728 & 0.209 & 1.790 & 0.949 & 0.195 & 0.638 \\
LEV & 2.324 & 1.177 & 10.13 & 8.676 & 0.799 & 2.291 & 1.193 & 1.203 & 1.632 \\
L1 & 0.235 & 0.952 & 0.072 & 0.081 & 0.325 & 0.067 & 0.744 & 0.882 & 0.149 \\
L2 & 1.010 & 1.499 & 1.104 & 1.179 & 0.937 & 0.807 & 1.486 & 2.050 & 0.913 \\
ROA & 0.094 & 0.081 & 0.015 & 0.016 & 0.273 & 0.056 & 0.185 & 0.021 & 0.018 \\
ROE & 0.159 & 0.075 & 0.176 & 0.157 & 0.149 & 0.221 & 0.276 & 0.028 & 0.019 \\
\hline
\end{tabular}

Source: Amadeus, 2018 (author's calculation) 
V: Expected Relationships between Stock Prices and Economic Factors

\begin{tabular}{lcccccc}
\hline Macro-factors & GAV & HIPP & INDP & GDP & UNE & CPI \\
price & positive & negative & positive & positive & negative & negative \\
Micro-factors & DE & LEV & L1 & L2 & ROA & ROE \\
price & negative & positive & positive/negative & positive/negative & positive & positive \\
\hline
\end{tabular}

Source: Author's expectations

on stock prices are captured in the Tab. V. Positive impact is expected for the GAV, INDP, GDP, LEV, ROA and ROE indicators. On the contrary, the negative impact can be assumed for HIPP, UNE, CPI and DE indicators. The relationship with liquidity is unclear, where too much growth in ratios can negatively affect the otherwise positive relationship to the company's business and stock price.

\section{Methodology}

The time series analysis was used to determine the impact of the macroeconomic environment on the stock prices of companies and for the construction of CAPM. Cointegration analysis uses time series data mainly due to the use of a sufficient time series in the form of quarterly data and for the identification of long-term relationships of individual enterprises, especially when determining deviations from the long-term equilibrium position. In constructing CAPM, it is necessary to include the individual results of the beta factors of individual companies for the subsequent capture of SML. Conversely, the panel data analysis has been used to determine the impact of the microeconomic environment on stock prices, due to the use of annual enterprise financial data. Thus, in this case, the panel data provides a higher reporting value for the resulting models than would be the case with the time series data.

At first, for the purpose of this article, the internal value of stock prices and expected rate of return is calculated. According to Markowitz (1952) or Sharpe (1964), this relationship can be interpreted as follows: the investor's rate of return is composed of the risk-free rate of return and the risk premium, the investor's remuneration for taking the risk. The line created by the derivation of the relevant quantities is called the Security market line (SML) and puts in relation risk and yield (1).

$E\left(r_{i}\right)=\beta\left(E\left(r_{m}\right)-r_{f}\right)$,

where $E\left(r_{i}\right)$ is the expected rate of stock return, $r_{f}$ is the free risk rate of return, $\beta$ measures the systematic risk of the assets, and $E\left(r_{m}\right)$ represents the expected market rate of return.

After determining the expected rate of return, it is important for investors to determine the relationship between stock price developments and macroeconomic indicators. Pearson correlation matrix and Johansen's cointegration test are the most commonly analyses used for the long-term causal relationship between variables (Johansen and Juselius, 1990), (Barbič and Čondič, 2011) or (Kulhánek, 2012). The test examines the possibility of fluctuation of the ranges in the short term, but in the long run, an equilibrium state should be achieved (Cipra, 2008). During testing, it is necessary to work with non-stationary time series that are stationary on the first difference and with the optimal time lag for a given file for which VAR models are used. If there is a causal relationship between the variables examined, it is quantified by the cointegration equation (2) used in the Johansen and Juselius (1990) study. Where Yt is the vector of the non-stationary dependent variable, CO is the constant in the cointegration equation, $n_{t}$ is the term for the white noise, the coefficients $C$ and $\Pi$ used in the matrix contain the individual cointegration vectors of the independently variable time series.

$\Delta \mathrm{Y}=\mathrm{C}_{0}+\sum_{i=1}^{p-1} \Gamma_{i} \Delta Y_{t-i}+\Pi Y_{t-1}+\eta_{t}$

If the factors are non-stationary and the cointegration vectors were found, the method to investigate the issue of causation is the Vector Error Correction Model (VECM), which is a Vector Autoregressive Model (VAR) in first differences with the addition of a vector of cointegrating residuals. Therefore, this VAR system does not lose long-run information

This analysis between microeconomic factors and stock prices is appropriate to use according to studies by Fleming (1998), or Hansen (1982). The Generalized method of moments (GMM) is a regression method using for linear relationship based on the annual data frequency (3). The relationship between the selected financial indicators related to the structure of the sources of financing and the solvency of the enterprises can be expressed using the following equation (Hall, 2005):

$L_{i t}=\alpha_{1}+\beta_{1} \times \Delta L_{i t-1}+\beta_{2} \times X_{1 i t}+\beta_{3} \times X_{2 i t}+\beta_{n} \times$

$\times X_{n i t} \times \varepsilon_{i t}$

where $\mathrm{L}_{\mathrm{it}}$ represents the dependent variable (stock prices), $\Delta \mathrm{L}_{\mathrm{it}-1}$ is an explanatory variable representing the delayed $\mathrm{L}$ value of the previous year, $\mathrm{X}_{\text {nit }}$ includes explanatory variables for which selected financial indicators related to the structure of sources of financing are considered to have an effect on the solvency of enterprises. The $\varepsilon_{i t}$ character 
represents the residual component of the model within the GMM. For the robustness of the model, the Sargan / Hansen J - statistics test is used.

\section{RESULTS}

The CAPM model is applied to the current PX exchange market values. The values for the expected return of stocks were available for the companies listed in the Tab. VI, where you can also see the Beta risk of individual companies based on the three-month average of values and the estimated return rate with which investors can then compare the calculated market yields of the shares. The risk free rate is derived from the yield of the ten-year government bond of the Czech Republic (1.70\%) and the risk premium based on the yield rate of the stock index PX (7.46\%). The resulting values are subsequently used for SML line construction in Fig. 3. This line may be the basis for the investors' decision to buy or sell the share.

The factor of beta risk is important because it measures the risk of an investment that cannot be diversified. It does not measure the risk of investing on a stand-alone basis, but the degree of risk that an investment contributes to an already diversified portfolio. In CAPM, beta risk is the only type of risk for which investors should receive the expected return higher than the risk-free interest rate. Beta below value 1 may indicate either investments with lower volatility than a market or volatile investment whose price movements are not very correlated with the market. Beta higher than 1 generally means that the asset is volatile and tends to move up and down with the market. The results in Tab. VI show that beta factor greater than 1 has only E4U and Erste Group Bank. On the other hand, the lowest coefficients of beta factor are reached by Energ., Jáchymov, Pegas, Pražské služby, TMR and Toma. Results of beta factors and expected rate of stock return are the main tools for constructing SML. This is a useful tool in determining whether an asset that is considered in the portfolio offers a reasonable expected return on risk. Individual securities are plotted on the SML chart. If the risk against the expected return is above the SML, it is underestimated as the investor can expect a higher return on the natural risk.

For the decision to buy or sell shares, it is important to monitor the macroeconomic and microeconomic factors have on the stock prices an immediate impact. The first step to determine the relationship between macroeconomic fundamentals and stock prices is to describe the correlation between variables. The correlation coefficient determines the bond strength between the variables examined and reaches values from -1 to 1 . The correlation relationship between the variables and the statistical significance of the individual coefficients is described in Tab. VII.

Based on the resulting correlation coefficients, it can be concluded that there is a positive relationship between gross added value and stock prices.

\section{VI: Results of Capital Asset Pricing Model (CAPM)}

\begin{tabular}{lccccccccc}
\hline Com & CEM & CEZ & E4U & Energ. & $\begin{array}{c}\text { Erste Group } \\
\text { Bank }\end{array}$ & Fortuna & Jáchymov & Kofola & $\begin{array}{c}\text { Komer. } \\
\text { Banka }\end{array}$ \\
\hline $\boldsymbol{\beta}$ & 0.23 & 0.90 & 2.22 & -0.23 & 1.59 & 0.37 & -4.21 & 0.33 & 0.85 \\
\hline $\boldsymbol{E}\left(\boldsymbol{r}_{\boldsymbol{i}}\right)$ & 3.02 & 6.88 & 14.48 & 0.37 & 10.85 & 3.83 & -22.55 & 3.60 & 6.59 \\
Com & $\begin{array}{c}\text { Moneta } \\
\text { Money Bank }\end{array}$ & $\mathbf{O 2}$ & $\mathbf{P e g a s}$ & $\begin{array}{c}\text { Philip } \\
\text { Morris }\end{array}$ & $\begin{array}{c}\text { Pražské } \\
\text { služby }\end{array}$ & TMR & Toma & Unipet. & VGP \\
\hline $\boldsymbol{\beta}$ & 0.72 & 0.73 & 0.08 & 0.27 & -1.12 & -0.25 & 0.04 & 0.31 & 0.17 \\
\hline $\boldsymbol{E}\left(\boldsymbol{r}_{\boldsymbol{i}}\right)$ & 5.85 & 5.90 & 2.16 & 3.25 & -4.75 & 0.26 & 1.93 & 3.48 & 2.68 \\
\hline
\end{tabular}

Source: Authors' calculations

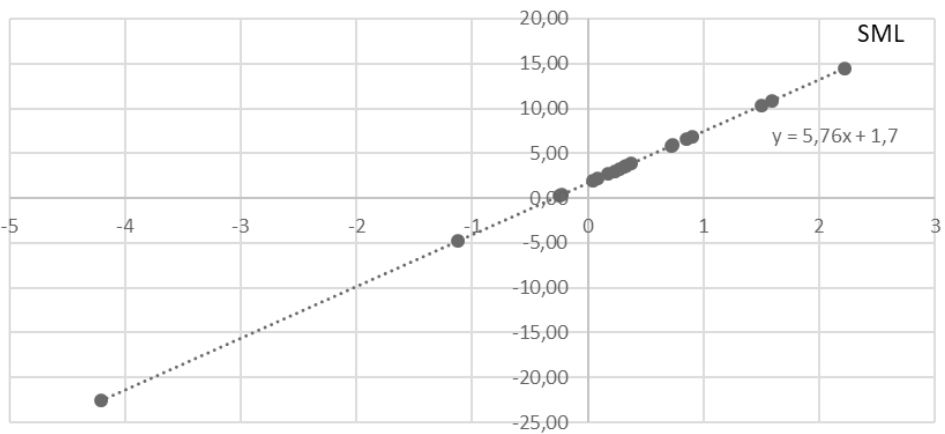

3: Security Market Line (SML)

Source: Authors' calculations 
A strong and slightly positive statistically significant relationship was demonstrated in ERST, PEG and UNIP stock prices. The opposite prevailing negative correlation was demonstrated for the harmonized index of industrial prices. A statistically significant relationship was demonstrated in 8 out of 9 cases and the strongest statistically significant negative links were achieved within the CEZ share price.

The predominant positive correlation relationship was confirmed between stock prices and industrial production. Positive statistically significant medium strong correlation was found for ERST, PEG and UNIP. Similarly, the gross domestic product has a positive effect on stock price developments. A statistically significant strong correlation was achieved with ERST and PEG.

For the last two macroeconomic variables, a prevailing negative relationship was found. However, in the case of an unemployment rate, this claim cannot be fully confirmed. A moderate relationship was seen in ERST, O2 and UNIP. The statistically significant strong price to equity ratio of the Consumer Price Index has been demonstrated at PHIL. The remaining statistically significant linkages between the variables examined are weak. However, it is preferable to use cointegration analysis to determine the long-term relationship. Based on the Johansen and Juselius studies, a cointegration analysis was developed in the Eviews program. Tab. VIII shows cointegration coefficients and their statistical significance at a given level of confidence. The number of cointegration relationships is based on Trace and Max Eigen Value statistics. A panel cointegration analysis was used to determine the possible relationship between the variables. The resulting statistically significant relationships were subsequently subjected to individual cointegration analyzes.

Before the cointegration relationship, it was necessary to choose an appropriate macroeconomic indicator delay using the VAR model and the Akaike information criterion. In this case, this is a statistically significant 2-quarter delay. Due to the large number of selected macroeconomic functions, two Johansen cointegration analyzes were performed. The first model includes industrial performance indicators, namely the gross added value, the harmonized index of production prices and industrial production. The second model includes the basic economic characteristics of the gross domestic pro-duct, the unemployment rate and the consumer price index.

From the Johansen analysis results, it is only possible for ČEZ and O2 companies to do not reject the zero hypothesis of no cointegration in industrial macroeconomic indicators. Other models showed

VII: Correlation coefficients between macroeconomic fundamentals and stock prices

\begin{tabular}{lccc|ccc}
\hline & GAV & HIPP & INDP & GDP & UNE & CPI \\
\hline ČEZ & 0.1948 & $-0.4559^{*}$ & 0.0754 & $0.261^{* * *}$ & $-0.333^{* *}$ & -0.1652 \\
ENER & 0.1079 & $-0.6353^{*}$ & 0.0567 & 0.1356 & 0.1939 & $-0.313^{* *}$ \\
ERST & $0.6297^{*}$ & $0.3291^{* *}$ & $0.5635^{*}$ & $0.6677^{*}$ & $-0.4396^{*}$ & 0.1729 \\
KOME & $0.3941^{*}$ & -0.1363 & $0.3516^{* *}$ & $0.3931^{*}$ & 0.1259 & -0.1551 \\
O2 & 0.2094 & $-0.338^{* *}$ & 0.1152 & $0.259^{* * *}$ & $-0.4668^{*}$ & -0.1824 \\
PEG & $0.5996^{*}$ & $-0.298^{* *}$ & $0.5511^{*}$ & $0.6709^{*}$ & -0.1015 & $-0.296^{* *}$ \\
PHIL & $0.263^{* * *}$ & $-0.254^{* * *}$ & $0.4319^{*}$ & $0.281^{* * *}$ & $0.4088^{*}$ & $-0.6525^{*}$ \\
TOMA & -0.1617 & $-0.4503^{*}$ & -0.0818 & -0.1676 & $0.3495^{* *}$ & $-0.392^{* *}$ \\
UNIP & $0.5436^{*}$ & $0.5532^{*}$ & $0.5326^{*}$ & $0.5690^{*}$ & $-0.5597^{*}$ & 0.2079 \\
\hline
\end{tabular}

Note: $* * *, * * *$ denote significance at $1 \%, 5 \%$ and $10 \%$ levels.

Source: Authors' calculations

VIII: Results of Johansen cointegration tests

\begin{tabular}{lcccc|cccc}
\hline & const & GAV & HIPP & INDP & const & GDP & UNE & CPI \\
\hline ČEZ & $\mathrm{X}$ & $\mathrm{x}$ & $\mathrm{x}$ & $\mathrm{x}$ & -302.02 & $279.08^{* *}$ & 2.76 & -280.23 \\
ENERGO & -37841 & 389.47 & 282.53 & $-316.98^{* *}$ & -49547 & 669.38 & 437.64 & -659.29 \\
ERSTE & 25500 & -230.97 & -106.39 & $78.20^{* *}$ & -11588 & $-388.0^{* *}$ & $175.87^{* *}$ & 310.17 \\
KOMER & -1249 & 0.14 & 29.14 & $-24.60^{* *}$ & 22597 & 598.04 & -117.10 & -704.22 \\
O2 & $\mathrm{X}$ & $\mathrm{x}$ & $\mathrm{x}$ & $\mathrm{x}$ & -6963 & 66.02 & 34.72 & -34.82 \\
PEGAS & -528 & $11.03 * *$ & $39.79 * *$ & $-47.35^{* *}$ & 14962 & $99.58^{* *}$ & -17.55 & -233.37 \\
PHILLIP & -31277 & 2773.25 & 1575.28 & $-1360.1^{* *}$ & 171149 & 3465.71 & -1566.22 & -3602.7 \\
TOMA & -13703 & 97.98 & 76.16 & $-44.87^{* *}$ & 2063 & 180.31 & -87.61 & -114.78 \\
UNIP & 2753 & -26.18 & -15.01 & 12.17 & -7621 & -103.65 & 54.38 & 119.70 \\
\hline
\end{tabular}

Note: ${ }^{* * *}, * * *$ denote significance at $1 \%, 5 \%$ and $10 \%$ levels.

Source: Authors' calculations 
at least one cointegration link. The results shown on Tab. IX describe that the statistically significant cointegration link was most evident in the INDP and GDP indicators. While the correlation between stock prices and INDP is negative, when INDP growth results in a future decline in the company's stock price, GDP is positive and GDP growth is rising as well. Although even in the case of other models, the effect of cointegrating vectors of macroeconomic variables was demonstrated, specific relationships were not statistically significant, even if, for example, CPI results indicate a high probability of negative binding. However, in all models with cointegrating vectors, VECM analysis was performed to compensate for long-term deviations from the equilibrium position.

The VECM results show that the model outperformed only the minimum deviation from long-term values in the observed period. Although the model corrected and equaled almost $50 \%$ of the total variability of the KOMER share price or $22.5 \%$ of the UNIP variability, it did not explain more than $2 \%$ of the fluctuations in macroeconomic indicators. For the UNE variable, it was statistically significant in all cases, but explained a very low variability value. Based on these suggestions, the results of Johansen's cointegration analysis can be seen as conclusive.

Besides the macroeconomic environment, the company's internal factors also affect the stock price. Based on the literature review, the basic financial ratios were chosen, most often followed by the management of the company and the investors themselves. Due to the availability of mostly annual final reports, only 11 surveys remained for each enterprise. Based on the literature review, it was advisable to use the panel regression method of the GMM, which can be used to evaluate the relationship with even fewer observations. Monthly average stock prices for the year were also used for the calculation, which would better capitalize on stock price developments than the price at the end of the period. Tab. X described the correlation matrix with linear correlation relationship between stock prices and microeconomic variables. The resulting regression equations of the model (4), (5) are further subjected to the Sargen / Hansen model robustness test.

The positive linear correlations relationship between observed variables was confirmed for the variables of L1, L2, ROA and ROE. Correlation analysis provides a basic characteristic of the link between the development of individual indicators, but the impact of individual microeconomic indicators on stock prices may be different. The analysis of the impact between financial indicators and stock prices is divided into two parts due to the high similarity and correlation between the various indicators of liquidity, indebtedness and profitability. Only the result of the leverage ratio was not statistically significant and was not

IX: Results of the Vector Error Correction Models

\begin{tabular}{|c|c|c|c|c|c|c|c|c|}
\hline & Stock & GAV & HIPP & INDP & Stock & GDP & UNE & CPI \\
\hline ENERGO & $-0.061^{*}$ & -0.0003 & $-0.0008^{*}$ & -0.0003 & $0.0202 *$ & -0.0001 & $-0.0002 *$ & -0.0007 \\
\hline ERSTE & 0.0631 & $0.0034^{*}$ & $0.0025^{*}$ & $0.0072^{*}$ & 0.0177 & $0.0007^{*}$ & $0.0004^{*}$ & -0.0002 \\
\hline KOMER & $-0.479 *$ & $0.0070^{*}$ & -0.0044 & 0.0071 & -0.0087 & -0.0002 & $-0.0002 *$ & 0.0002 \\
\hline $\mathbf{O} 2$ & x & x & X & x & 0.0211 & -0.0028 & $-0.0022 *$ & 0.0015 \\
\hline PHILLIP & -0.0585 & $-0.0002 *$ & $-0.0001^{*}$ & $-0.0004 *$ & -0.0311 & -0.0003 & $-0.0004 *$ & 0.0002 \\
\hline TOMA & 0.0802 & $-0.0065^{*}$ & $-0.0047^{*}$ & $-0.0159 *$ & -0.0173 & $-0.0012 *$ & $-0.0008^{*}$ & 0.0003 \\
\hline UNIP & $-0.225^{*}$ & $0.0190 *$ & $0.0171^{*}$ & 0.0143 & -0.0178 & $0.0020^{*}$ & $0.0014 *$ & -0.0007 \\
\hline
\end{tabular}

Note: $*$, **,*** denote significance at $1 \%, 5 \%$ and $10 \%$ levels.

Source: Authors' calculations

$\mathrm{X}$ : Correlation matrix of the relationship between stock prices and microeconomic variables

\begin{tabular}{lccccccc}
\hline & Price & DE & LEV & L1 & L2 & ROA & ROE \\
\hline Price & 1 & -0.1293 & -0.1103 & $0.3741 *$ & $0.2015^{* *}$ & $0.3342^{*}$ & $0.4478^{*}$ \\
DE & -0.1293 & 1 & $0.9961^{*}$ & $-0.4618^{*}$ & -0.1625 & $-0.4067 *$ & $0.2469 * *$ \\
LEV & -0.1103 & $0.9961^{*}$ & 1 & $-0.4489^{*}$ & -0.1588 & $-0.4189 *$ & $0.2544 * *$ \\
L1 & $0.3741^{*}$ & $-0.4618^{*}$ & $-0.4489 *$ & 1 & $0.6301^{*}$ & $0.2371 * *$ & -0.1022 \\
L2 & $0.2015^{* *}$ & -0.1625 & -0.1588 & $0.6301 *$ & 1 & -0.0174 & $-0.1689 * * *$ \\
ROA & $0.3342^{*}$ & $-0.4067 *$ & $-0.4189 *$ & $0.2371^{* *}$ & 0.2371 & 1 & $0.4229 *$ \\
ROE & $0.4478^{*}$ & $0.2469 * *$ & $0.2544 * *$ & -0.1022 & $-0.1689 * *$ & $0.4229 *$ & 1
\end{tabular}

Note: $*, * *, * * *$ denote significance at $1 \%, 5 \%$ and $10 \%$ levels.

Source: Authors' calculations 
included in the resulting equation of the second model. Regressions results of Panel Generalized Method of Moments of the first model is described in Tab. XI.

Stock Prices $=0.5372$ Stock Prices $(-1) \times$ × $1561.33 \mathrm{ROA}^{*}-25.623 \mathrm{~L}^{*}+21.565 \mathrm{DE}^{*}$

Based on the probability results, it is possible to determine which regression coefficients are statistically significant. For Prob. less than the significance level of 0.05 can be rejected a zero hypothesis that the coefficients are statistically insignificant. According to the statistically significant results of the regression equation $(*)$ of model 1 , the ROA indicator, which positively influences the development of stock prices, has the most significant influence on the prices of the selected companies in the Czech Republic. Positive dependence was also found for the DE indicator and, on the other hand, the negative dependence was demonstrated for the liquidity indicator L2. It can also be assumed that the stock price will have a positive effect on the value of the delayed share price (Stock Prices (-1)). Based on the Sargan / Hansen test Cross-section of fixed orthogenic deviations with J-statistics 8.7443 and Prob. 0.1884. For this reason, the $\mathrm{HO}$ cannot be rejected and the model is statistically significant.

Stock Prices $=0.6344$ Stock Prices $(-1)+$ + 1227.27 ROE* + 937.481 Ll*

Based on the probability results in Tab. XII, it is possible to determine which regression coefficients are statistically significant. For Prob. less than the significance level of 0.05 can be rejected a zero hypothesis that the coefficients are statistically insignificant. The resulting values of the model 2, which tracks the statistically significant ROE and Ll ratios, confirms the results of the first model, with the greatest impact on stock price being the profitability indicator. On the other hand, this model has a positive liquidity effect on the stock price, which can be explained by a specific focus on the liquidity indicator L1. The coefficient of stock price will have also a positive effect on the value of the delayed share price (Stock Prices (-1)). Based on the Sargan/Hansen test Cross-section of fixed orthogenic deviations with J-statistics 6.1640 and Prob. 0.4051. For this reason, the HO cannot be rejected and the model is statistically significant.

XI: Results of Panel GMM (model 1)

\begin{tabular}{ccccc}
\hline Variable & Coefficient & Std. Error & t-Statistic & Prob. \\
\hline Stock Prices (-1) & 0.5372 & 0.0007 & 717.6988 & 0.0000 \\
ROA & 1561.3300 & 60.4678 & 25.8208 & 0.0000 \\
L2 & -25.6230 & 10.1653 & -2.5206 & 0.0138 \\
DE & 21.5651 & 3.5018 & 0.0000 \\
\hline \multicolumn{5}{c}{ Effects Specification } \\
\hline Cross-section fixed (orthogonal deviations) \\
\hline Mean dependent var & -250.4173 & S.D. dependent var & 666.4660 \\
S.E. of regression & 606.0837 & Sum squared resid & 28284979 \\
J-statistic & 8.7443 & Instrument rank & 10 \\
Prob(J-statistic) & 0.1884 & Number of observations & 81 \\
\hline
\end{tabular}

Source: Authors' calculations

XII: Results of Panel GMM (model 2)

\begin{tabular}{ccccc}
\hline Variable & Coefficient & Std. Error & t-Statistic & Prob. \\
\hline Stock Prices (-1) & 0.6344 & 0.0125 & 50.3766 & 0.0000 \\
LEV & 13.78496 & 9.2752 & 1.4862 & 0.1413 \\
Ll & 937.4812 & 81.2211 & 11.5423 & 0.0000 \\
ROE & 1227.271 & 479.6725 & 2.5585 & 0.0125 \\
\hline \multicolumn{5}{c}{ Effects Specification } \\
\hline Mean dependent var & Cross-section fixed (orthogonal deviations) \\
\hline S.E. of regression & -250.4173 & S.D. dependent var & 666.4660 \\
J-statistic & 563.6320 & Sum squared resid & 24461440 \\
Prob(J-statistic) & 6.1640 & Instrument rank & 10 \\
\hline
\end{tabular}

Source: Authors' calculations 


\section{DISCUSSION}

The capital market in the Czech Republic is currently characterized by stable stock price developments as a result of the positive economic situation. Based on the CAPM calculation and the subsequent SML line, the PX market can be valued by equity returns if the individual shares are underestimated or overestimated. Expected share returns due to changes in stock prices may affect the economic environment. For this reason, the effect of macroeconomic and microeconomic factors on stock prices is characterized in this paper. Using Pearson's correlation analysis and Johansen cointegration analysis, it can be concluded that the resulting relationships between stock prices and macroeconomic factors predominantly confirm the expected relationships. Statistically significant long-term relationships have been demonstrated for indicators of the industrial production index and the gross domestic product index.

From the long-term causal relationship using the Johansen cointegration method, it can be assumed that industrial production with a two-quarter delay neglects stock prices, which does not confirm the expected results. Although the growing production has an immediate positive effect on the profit of the companies and thus also on the stock price, the reaction of the delayed period negatively affects the prices of the selected stock titles. This can be attributed to a situation where the increase in production cannot be done without increasing the production capacity of enterprises and higher capital expenditures reduce the likelihood of surplus cash being paid, which has a negative effect on the share price. The second statistically significant macroeconomic indicator is the indigenous gross domestic product index. This indicator has a positive effect on stock prices, where the good economic situation, supported by steady economic growth, positively affects the profit of companies and the share price increase.

The regression analysis results confirm the expected relationships in all cases. The negative relationship between stock prices and the debt equity ratio points to the fact that the increase in debt equity ratios generally means that the company has been aggressive in financing its growth with debt. Aggressive leveraging practices are often associated with high levels of risk. According to the result of panel regression, the change in DE ration per unit will reduce the share price by 21.5 units.

The resulting relationship between L2 and stock prices is negative when the liquidity indicator was negatively affected by the receivables of companies with higher receivables declining the current value of shares where the non-payment of the receivable is related to the cost of its recovery and with the growth of the L2 indicator per unit, the share price will decrease by 25.6 units. On the other hand, the resulting relationship between Ll liquidity and stock prices confirms the hypothesis that the growth of the Ll and thus the increase in financial assets or the reduction of short-term liabilities will be reflected in the rise in stock prices. According to the resulting coefficient, it can be argued that with the growth of the L1 indicator per unit, the share price will increase by 937.6 units

The highest impact on stock prices was demonstrated by the profitability ratios, specifically return on assets and return on equity, whereby the more profitable the company is, the abler it is to pay dividends. The company's growing profitability is therefore positively reflected in the total value of the company and hence in the share prices, thus the high resultant coefficient is a positive effect, with a unit price increase by 1561.3 units in the case of ROA and by 1227.3 units in the case of ROE.

\section{CONCLUSION}

The aim of this paper was to examine the nature of the relationship between stock price development and economic factors in the Czech Republic. Using the CAPM, correlation analysis, Johansen cointegration analysis and the GMM method, the relationships between the surveyed variables in PX listed companies were analyzed, the time series of which included data for the period 2006-2016.

Portfolio theory seeks to explain how the investor can maximize yield and minimize the associated risk. Based on the CAPM results and the expected return rate, a SML line was constructed to determine whether the selected stock yield on the PX market is overvalued or underestimated. It was also necessary to analyze the impact of the economic environment on stock price developments to decide whether to buy or sell a share.

The results of the correlation analysis showed the correlation between the unaddressed macroeconomic variables and the share price of individual companies. The statistically significant positive binding showed GAV, INDP, GDP. The growth of these macro indicators triggered an immediate rise in stock prices. On the contrary, a statistically significant negative relationship was found for UNE, HIPP and CPI, the decline of which would also result in a fall in stock prices. These results confirmed the expected results based on economic theories. In the long run, however, macroeconomic indicators tend to act with some delay. Based on this theory, Johansen's cointegration analysis was used to determine the long-term relationship, which, according to VAR tests, worked with two quarterly delays. The results of the analysis resulted in the observation that industrial production with delays negatively affects stock prices in particular to industrial companies. This can be attributed to a situation where the increase of production cannot be done without increasing the production 
capacity of the enterprises and higher capital expenditures reduce the likelihood of surplus cash being paid, which has a negative effect on the share price.

The second typical delayed variable is the gross domestic product, which has a positive effect on the share price. Everything is due to the fact that the stock price reflects future profits. Thus, if investors anticipate a positive development of GDP, they buy shares that grow in value. Stock market growth then stimulates a wave of optimism and affects the behavior of both businesses and consumers. This then leads to higher investment activity and eventually will actually affect the real output of the economy.

In the case where the cointegration vectors were proven according to the Johansen cointegration analysis, the deviations from the long-term equilibrium were eliminated using the VECM model. However, this analysis explained only a small part of variability and therefore the results of cointegration analysis can be considered statistically significant.

Stock market conditions also affect business conditions. Based on the final reports, the basic ROA, L2 and debt-equity ratios have been calculated, which, according to the theory, impose a price on stocks. Thanks to the annual time series and a small number of companies on the PX market, panel analysis using the GMM regression method was performed. Based on the results, it can be argued that all three selected variables have a significant impact on the share price, with the largest ROA indicator. The robustness of the model confirms the impact of individual microeconomic indicators on the stock price. These results are useful in generating an advanced fundamental analysis, based on industry analyzes, to determine the internal price of an action and then apply the results.

\section{Acknowledgements}

Publication of this paper was supported by the Student Grant System of Silesian University in Opava within the project "The effect of fundamental factors and corporate governance on stock prices". The support is greatly acknowledged.

\section{REFERENCES}

ALI, M. B. 2011. Impact of Micro and Macroeconomic Variables on Emerging Stock Market Return: A Case on Dhaka Stock Exchange. Interdisciplinary Journal of Research in Business, 1(5): 8-16.

ANGHELACHE, G. V., KRALIK, L. I., ACATRINEI, M. and PETE, S. 2014. Influence of the EU Accession Process and the Global Crisis on the Cee Stock Markets: A Multivariate Correlation Analysis. Rom. J. Econ. Forecast, 17: 35-52.

BARBIĆ, T. and ČONDIĆ-JURKIĆ, I., 2011. Relationship between Macroeconomic Fundamentals and Stock Market Indices in Selected CEEC. Economic Review, 62(3-4): 113-133.

BAUER, P. 2004. Capital structure of listed companies in Visegrad countries. Prague Economic Papers, 2: $159-175$.

BISTROVA, J., LACE, N. and TITKO, J. 2013. CEE companies: Economic vs. market performance. In: 17th World Multi-Conference on Systemics, Cybernetics and Informatics, vol. 2. July 9-12, 2013, Orlando, Florida, USA, pp. 1-6.

CHEN, N.-F., ROLL, R. and ROSS, S. A. 1986. Economic Forces and the Stock Market. The Journal of Business, 59(3): 383-403.

CIPRA, T. 2008. Finanční ekonometrie. Praha: Ekopress.

CURRAN, M. and VELIC, A. 2018. The CAPM, National Stock Market Betas, and Macroeconomic Covariates: A Global Analysis. TEP Working Paper no. 0618. TEP.

CUTHBERTSON, K., HAYES, S. and NITSCHE, D. 1997. The Behaviour of UK Stock Prices and Returns: Is the Market Efficient? SSRN Scholarly Paper No. ID 1994198. Rochester, NY: Social Science Research Network.

FLANNERY M. J. and PROTOPAPADAKIS A. A., 2002. Macroeconomic Factors Do Influence Aggregate Stock Returns. The Review of Financial Studies Summer, 15(3): 751-782.

FLEMING, J. 1998. The quality of market volatility forecasts implied by S \& P 100 index option prices. Journal of Empirical Finance, 5(4): 317-345.

GJERDE, O. and F. S/ETTEM, 1999. Causal relations among stock returns and macroeconomic variables in a small, open economy. Journal of International Financial Markets, Institutions and Money, 9(1): 61-74.

HALL, A. R. 2005. Generalized Method of Moments (Advanced Texts in Econometrics). Oxford: University Press.

HANSEN, L. P. 1982. Large Sample Properties of Generalized Method of Moments Estimators. Econometrica, 50(4): 1029-1054.

JOHANSEN,S.andJUSELIUS,K.1990.Maximumlikelihoodestimationandinferenceoncointegration-withapplications to the demand for money. Oxford Bulletin of Economics and Statistics, no. 52. Oxford: Wiley-Blackwell on behalf of Blackwell Publishing Ltd and University of Oxford Department of Economics.

KULHÁNEK, L. 2012. The relationship between stock markets and gross domestic product in the Central and Eastern Europe. In: KOTLEBOVÁ, J. (Ed.). The $7^{\text {th }}$ International Conference on Currency, Banking and International Finance - How Does Central and Eastern Europe Cope up with the Global Financial Crisis. Bratislava: University of Economics in Bratislava. 
LUND, J. and ENGSTED, T. 1996. GMM and present value tests of the C-CAPM: evidence from the Danish, German, Swedish and UK stock markets. Journal of International Money and Finance, 15(4): 497-521.

MARKOWITZ, H., 1952. Portfolio Selection. The Journal of Finance, 7(1): 77-91.

PLACHY, R. and RASOVEC, T. 2015. Impact of Economic Indicators on Development of Capital Market. E + MEkon. Manag., 18: 101-112.

SAHADEV, K., WARD, M. and MULLER, C. 2018. The impact of reference-day risk on beta estimation and a proposed solution, Investment Analysts Journal, 47(4): 327-342.

SHARPE, W. F., 1964. Capital asset prices: A theory of market equilibrium under conditions of risk, Journal of Finance, 19(3): 425-442.

\section{List of Abbreviations}

\begin{tabular}{ll} 
CAPM & Capital asset pricing model \\
ČEZ & ČEZ AG \\
CPI & Consumer price index \\
DE & Debt-equity ratio \\
EMEA & Europe, Middle East and Africa \\
ENER & Energoaqua AG \\
ERST & Erste Group Bank AG \\
GAV & Gross added value \\
GDP & Index of real gross domestic product \\
GMM & Generalized method of moments \\
HIPP & Harmonized index of product prices \\
INDP & Index of industrial production \\
J-B test & Jarque Bera test \\
KOME & Komerční Banka AG \\
L1 & Cash position ratio \\
L2 & Current ratio \\
LEV & Financial leverage \\
O2 & O2 Czech Republic AG \\
PEG & Pegas Nonwovens AG \\
PHIL & Phillip Morris ČR \\
Prob. & Probability \\
PX & Prague Stock Exchange \\
ROA & Return on assets \\
ROE & Return on equity \\
SML & Security market line \\
TOMA & TOMA AG \\
UNE & Unemployment rate \\
UNIP & Unipetrol \\
VAR & Vector Autoregressive Model \\
VECM & Vector Error Correction Model \\
& \\
\hline
\end{tabular}

